\title{
PREDICTIVE VALUE OF PSA VELOCITY OVER EARLY CLINICAL AND PATHOLOGICAL PARAMETERS IN PATIENTS WITH LOCALIZED PROSTATE CANCER WHO UNDERGO RADICAL RETROPUBIC PROSTATECTOMY
}

\author{
CARLOS A.L. MARTINEZ, MARCOS DALL'OGLIO, LUCIANO NESRALLAH, KÁTIA M. \\ LEITE, VALDEMAR ORTIZ, MIGUEL SROUGI
}

Division of Urology, Paulista School of Medicine, Federal University of São Paulo (UNIFESP), São Paulo, SP, Brazil

\begin{abstract}
Objectives: To analyze the behavior of the prostate specific antigen velocity (PSAV) in localized prostate adenocarcinoma.

Materials and Methods: We conducted a retrospective study of 500 men who had localized prostate adenocarcinoma, who underwent radical retropubic prostatectomy between January 1986 and December 1999. The PSAV was calculated for each patient and subsequently, the values were correlated with 5 groups: age, initial PSA value, clinical stage, tumor volume and Gleason score.

Results: The behavior of PSAV presented statistic significance with an increment between $1.3 \mathrm{ng} / \mathrm{mL}$ and $9.6 \mathrm{ng} / \mathrm{mL}$, ranging from $38.6 \%$ and $59.8 \%$ when compared with the initial PSA value $(\mathrm{p}<0.0001)$, clinical stage $(\mathrm{p}=0.0002)$, tumor volume $(\mathrm{p}<0.0001)$ and Gleason score $(\mathrm{p}=0.0009)$.

Conclusion: PSAV up to $2.5 \mathrm{ng} / \mathrm{mL} / \mathrm{year}$ is associated with factors of good prognosis, such as initial PSA below $10 \mathrm{mg} / \mathrm{mL}$, clinical stage T1, tumor volume below $20 \%$ and Gleason score lower than 7.
\end{abstract}

Key words: prostate-specific antigen; prostatic neoplasms; pathology; neoplasm staging Int Braz J Urol. 2004; 30: 12-7

\section{INTRODUCTION}

Prostate cancer (PCA) is the most common cancer in males from Europe, North America and some African countries, occurring in $9.7 \%$ of all cancers in males, reaching $15.3 \%$ in developed countries and $4.3 \%$ in developing countries (1). Data from the Brazilian National Cancer Institute (http:// ww w.inca.gov.br/estimativas/2003/ index.asp?link=tableestados.asp\&UF=BR) estimate that, in 2003, 35,200 new cases of PCA will be diagnosed and 8,200 men should die as a consequence of it.
The most commonly used methods for detecting PCA are the digital rectal examination, the transrectal ultrasonography of the prostate and the prostate-specific antigen (PSA). The digital rectal examination has a sensibility between 40 and $80 \%$, specificity of $55 \%$ and a positive predictive value between 17 and 45\% (2). Transrectal ultrasound (TRUS) reaches detection rates between 2.3 and $14.6 \%$ with positive predictive value between 17 and $36 \%$, however, it presents low sensibility and specificity (3). Currently, the PSA is the main diagnostic test for PCA, being used for screening, prognosis, staging and cure control (4), however, the PSA is not an ideal marker, 
because it has a false positive index of 10 to $40 \%$ and positive predictive value of $46 \%$ (5). On the other hand, up to $20 \%$ of patients with prostate cancer have normal PSA (6).

Since the dosing of serum PSA is accompanied by failure, variants of PSA measurements were described in order to increase its accuracy: The free/ total PSA ratio (7), age-specific PSA (8), PSA density (9) and PSA velocity (PSAV) $(10,11)$.

The objective of this work is to determine the behavior of PSAV according to age, initial PSA value, clinical stage, tumor volume and Gleason score, in patients who underwent radical prostatectomy due to localized prostate adenocarcinoma.

\section{MATERIALS AND METHODS}

We conducted a retrospective, non-controlled, study based on the review of records from patients who underwent radical prostatectomy between January 1986 and December 1999. The patients included in this study were assessed and treated at São Paulo Hospital, from the Federal University of São Paulo, and Syrian Lebanese Hospital, São Paulo.

The study comprised 500 patients, with diagnosis of localized prostate cancer in stages T1c, T2a, T2b, T2c and T3a, who underwent radical retropubic prostatectomy (RRP) between 1986 and 1999, with ages ranging from 42 to 76 years with a mean age of 62.4 years.

For inclusion in the study, there was the requirement of at least 2 PSA values previously to diagnosis with an interval not lower than 6 months between both samples.

Exclusion criteria were previous prostatic surgery, prostatitis or urinary infection at the moment of any PSA measurement (Hybritech Tandem-R e Abbott $\operatorname{Imx})$.

Surgical specimens (prostate, seminal vesicles and lymph nodes) were evaluated by the same pathologist (KML), analyzing the following pathological parameters: histological grade, tumor volume, surgical margins, infiltration of extra-prostatic tissue, infiltration of seminal vesicles, lymph nodes metastases and pathologic stage of disease.
In order to calculate the PSAV, the patients were divided in 5 groups:

Group I = PSAV / Age - A) 40-49, B) 50-59,

C) $60-69$, D) < 70;

Group II = PSAV / Initial PSA value - A) 0-4,

B) $4.1-10$ C) $10.1-20$ D) $<20$

Group III = PSAV / Clinical stage - T1a-b-c, T2a-b, T2c-T3;

Group IV = PSAV / Tumor volume $(\mathrm{cc})-\mathrm{A})$ 0-20, B) 20-50, C) < 50;

Group V= PSAV / Gleason score - A) 2-3-45-6, B) 7-8-9-10.

\section{Evaluation Criteria}

The PSAV was calculated for each patient by the method of regression curve analysis in units/time and percentage/time.

\section{Statistical Analysis}

Non parametric tests were used; for 2 variables, we used the Mann-Whitney test and for 3 or more variables, we used the Kruskal-Wallis test. The $p$ value $<0.05$ was considered statistically significant.

\section{RESULTS}

\section{PSAV / Age in Years}

No statistically significant differences were found in PSAV between different age groups. The majority of patients under study $(81 \%)$ were in the range of 50-70 years (Table-1).

\section{PSAV / Initial PSA Value}

We found statistically significant differences in PSAV when PSA was $<10 \mathrm{ng} / \mathrm{mL}$. The PSA velocity reached $2.3 \mathrm{ng} / \mathrm{mL}$ when PSA $<10 \mathrm{ng} / \mathrm{mL}$, however, when PSA was higher than $10 \mathrm{ng} / \mathrm{mL}$ its velocity was higher than $5 \mathrm{ng} / \mathrm{mL}$ (Table-2).

\section{PSAV / Clinical Stage}

We found statistically significant difference in PSAV when confronting clinical stage T1 with T2cT3a, according to PSA results in different stages of disease, with the mean PSA in T1c tumors being equal to $3.5 \mathrm{ng} / \mathrm{mL}$, while in T2c-T3a tumors the mean reached $6 \mathrm{ng} / \mathrm{mL}$ (Table-3). 
Table 1 - PSA Velocity $(P S A V)$ in $n g / m L$ relative to Patient Age in years.

\begin{tabular}{lccrr}
\hline Age & Mean (PSAV) & Median (PSAV) & n & $\%$ \\
\hline $40-49$ & 4.6 & 3.3 & 20 & 4,0 \\
$50-59$ & 4.4 & 2.8 & 127 & 25.4 \\
$60-69$ & 4.2 & 2.7 & 278 & 55.6 \\
$70-79$ & 5.3 & 3.0 & 75 & 15.0 \\
\hline
\end{tabular}

$H=0.99 ; P=0.8037$

Table 2 - PSA Velocity (PSAV) in $n g / m L$ relative to Initial PSA Value.

\begin{tabular}{lccrr}
\hline PSA & Mean (PSAV) & Median (PSAV) & n & $\%$ \\
\hline $0-4$ & 1.5 & 1.3 & 36 & 7.2 \\
$4.1-10$ & 2.3 & 1.8 & 228 & 45.6 \\
$10.1-20$ & 5.2 & 3.9 & 171 & 34.2 \\
$<20$ & 11.5 & 9.6 & 65 & 13.0 \\
\hline
\end{tabular}

$H=176.29 ; P<0.0001$

\section{PSAV / Tumor Volume}

We found statistically significant difference in PSAV when the tumor volume was $<20 \%$ of the gland when compared to volumes between $21-50 \%$ and $>50$ (Table-4).

\section{PSAV / Gleason Score}

We found statistically significant differences in PSAV between the 2 groups (Table-5).

Table 3 - PSA Velocity (PSAV) in $\mathrm{ng} / \mathrm{mL}$ relative to Clinical Stage of prostate carcinoma.

\begin{tabular}{lcccc}
\hline Clinical Stage & Mean (PSAV) & Median (PSAV) & n & \% \\
\hline T1 & 3.5 & 2.5 & 188 & 37.6 \\
T2a-b & 4.6 & 2.8 & 218 & 43.6 \\
T2c-T3a & 6.0 & 3.6 & 94 & 18.8 \\
\hline
\end{tabular}

$H=16.68 ; P=0.0002$

Table 4 - PSA Velocity (PSAV) in $\mathrm{ng} / \mathrm{mL}$ relative to Tumor Volume.

\begin{tabular}{lcccc}
\hline Tumor Volume (\%) & Mean (PSAV) & Median (PSAV) & n & \% \\
\hline $0-20$ & 3.5 & 2.3 & 305 & 61.0 \\
$21-50$ & 5.0 & 3.5 & 148 & 29.6 \\
$<50$ & 9.3 & 5.2 & 40 & 8.0 \\
\hline$H=35.74, P<0.0001$
\end{tabular}

$H=35.74 ; P<0.0001$ 
Table 5 - PSA Velocity (PSAV) in ng/mL relative to Gleason Score.

\begin{tabular}{lcccc}
\hline Gleason & Mean (PSAV) & Median (PSAV) & n & \% \\
\hline $2-3-4-5-6$ & 3.9 & 2.5 & 312 & 62.4 \\
$7-8-9-10$ & 5.3 & 3.3 & 188 & 37.6 \\
\hline
\end{tabular}

$U=24146.0 ; P<0.0009$

\section{DISCUSSION}

Our results show that the behavior of PSAV compared to its initial value, clinical stage, tumor volume and Gleason score, present a significant variation in PSAV with an increment between $1.3 \mathrm{ng} / \mathrm{mL}$ and $9.6 \mathrm{ng} / \mathrm{mL}$, ranging from $38.6 \%$ to $59.8 \%$.

The difficulties for calculating the PSAV include its physiological variations between different tests, and the fact that PSA is not prostate cancer specific, limits its use, however, it is believed that PSAV has its maximal use for indicating biopsy for those patients with normal PSA or repeating the biopsy in cases of abnormal PSA (12).

Roehrborn et al. (13) studied the variability of PSA in less than 90 days, in 295 patients having BPH with PSA values below $10 \mathrm{ng} / \mathrm{mL}$, and found variations from 5.3 to $7.5 \mathrm{ng} / \mathrm{mL}$ between both PSA measurements. Additionally they found $19 \%$ of patients with an increment higher than $0.75 \mathrm{ng} / \mathrm{mL}$, concluding that the PSA variability in a short time interval is statistically significant.

An important study (14) compared the PSAV in patients with BPH and PCA and verified that the velocity was similar until 5 years before the diagnosis, however, between 7 and 9 years before the diagnosis the PSAV was higher in PCA. PSAV $<0.75 \mathrm{ng} /$ $\mathrm{mL} /$ year was detected 2.6 years before the diagnosis in $72 \%$ of PCA cases, showing higher accuracy with $\mathrm{PSA}<4.0 \mathrm{ng} / \mathrm{mL}$, increasing the specificity from $60 \%$ to $90 \%$ (14). Our study revealed that all patients had a PSAV higher than $1.3 \mathrm{ng} / \mathrm{mL} /$ year, almost twice the value found by Carter et al. (14). Maybe the explanation for such differences is due to the size of the sample, since Carter et al. (14) worked with a group of 11 patients with clinically localized carcinoma, and our study group included 500 patients with clinically localized carcinoma.
Smith \& Catalona (10) determined a PSAV above $0.75 \mathrm{ng} / \mathrm{mL} /$ year, as being the point of highest sensibility (79\%) and specificity (66\%) for detecting prostate cancer in those patients with initial PSA lower than $4 \mathrm{ng} / \mathrm{mL}$ and under 70 years old. For initial PSA higher than $4 \mathrm{ng} / \mathrm{mL}$ the cut-off point of highest sensibility and specificity for detecting cancer was PSAV of $0.4 \mathrm{ng} / \mathrm{mL} /$ year or more (10). Another study (15) identified different values, finding a PSAV of $0.6 \mathrm{ng} /$ $\mathrm{mL} /$ year for patients with initial PSA lower than 4 $\mathrm{ng} / \mathrm{mL}$, and $1.0 \mathrm{ng} / \mathrm{mL} /$ year for patients with initial PSA value higher than $4 \mathrm{ng} / \mathrm{mL}$, in a group of 2,999 patients followed during 5 years for PCA screening.

Another study (16) with patients showing PSA between 2.5 and $4 \mathrm{ng} / \mathrm{mL}$, diagnosed $\mathrm{BPH}$ and PCA by calculation of PSAV, being $0.38 \mathrm{ng} / \mathrm{mL} /$ year and $0.52 \mathrm{ng} / \mathrm{mL} /$ year for BPH and PCA respectively, additionally it showed a higher PSAV in younger patients. In contrast, our study revealed PSAV of 59\% and $1.3 \mathrm{ng} / \mathrm{mL} /$ year in the group of patients with PSA lower than $4,0 \mathrm{ng} / \mathrm{ml}$. Our results did not show statistically significant differences concerning age.

Thiel et al. (17) analyzed the PSAV and its role in the final pathologic prediction of PCA. They detected a PSAV value of $1.1 \mathrm{ng} / \mathrm{mL} /$ year for localized disease, and $1.9 \mathrm{ng} / \mathrm{mL} /$ year for non-confined disease.

We observed that there is variability in the literature regarding the sensibility and specificity of PSAV, with values from $55 \%$ to $79 \%$ and $66 \%$ to $96 \%$ $(11,13,18)$ respectively.

When the PSAV was higher than $0.75 \mathrm{ng} / \mathrm{mL} /$ year the diagnosis of PCA was 47 to $70 \%$ (14), however, when the PSA is lower than $4 \mathrm{ng} / \mathrm{mL}$, the prostate biopsy is indicated when PSAV is lower than $20 \%$ per year (19). In comparison to our results, all patients with PSAV higher than $1.3 \mathrm{ng} / \mathrm{mL} /$ year and higher than $38.6 \%$ correlated to the diagnosis of prostate cancer. 
Finally Schmid et al. (20) when studying 43 patients with untreated PCA, confirmed the doubling time of PSA through sequential measurements, and found that those patients with adverse factors showed a doubling time significantly shorter than those with favorable prognostic factors ( 24 versus 48 months in average). Such data can be applied to our results; if we analyze the PSAV values correlating them with factors that are associated with a good prognosis, we can observe that generally those patients with favorable elements such as low initial PSA, impalpable tumors, low Gleason and smaller tumors, have PSAV about $2.5 \mathrm{ng} / \mathrm{mL} /$ year.

One critic to the present study, would be the difficulty of working with PSAV due to the test's large variability, caused mainly by physiological variations and by the discrepancy between the different tests employed.

Definitively it is impossible to reach a $100 \%$ level of sensibility and specificity with PSA, even if we create an ultra-sensitive PSA we will be able to reach the ideal level. This is valid for PSAV as well.

Since this is the only available work on the behavior of PSAV in patients with localized prostate cancer including an expressive number of patients, it is necessary to perform prospective and randomized studies in order to confirm such findings.

\section{CONCLUSION}

A low PSAV (about $2.5 \mathrm{ng} / \mathrm{mL} /$ year) was associated with factors of good prognosis such as initial PSA lower than $10 \mathrm{ng} / \mathrm{mL}$, clinical stage T1, tumor volume lower than $20 \%$ and Gleason score lower than 7 , not changing with age.

\section{REFERENCES}

1. Gronberg H: Prostate cancer epidemiology. Lancet. 2003; 361: 859-64.

2. Catalona WJ, Richie JP, Ahmann FR, Hudson MA, Scardino PT, Flanigan RC, et al.: Comparison of digital rectal examination and serum prostate specific antigen in the early detection of prostate cancer: results of a multicenter clinical trial of 6,630 men. J Urol. 1994; 151: 1283-90.
3. Brawer MK: Prostate cancer. J Urol. 1997; 157: $207-$ 8.

4. Wang MC, Valenzuela LA, Murphy GP, Chu TM: Purification of a human prostate specific antigen. Invest Urol. 1979; 17: 159-63.

5. Abrahamsson PA, Lilja H, Oesterling JE: Molecular forms of serum prostate-specific antigen. The clinical value of percent free prostate-specific antigen. Urol Clin North Am. 1997; 24: 353-65.

6. Benson MC, Whang IS, Pantuck A, Ring K, Kaplan SA, Olsson CA, et al.: Prostate specific antigen density: a means of distinguishing benign prostatic hypertrophy and prostate cancer. J Urol. 1992; 147: 815-6.

7. Catalona WJ, Smith DS, Wolfert RL, Wang TJ, Rittenhouse HG, Ratliff TL, et al.: Evaluation of percentage of free serum prostate-specific antigen to improve specificity of prostate cancer screening. JAMA. 1995; 18; 274: 1214-20.

8. Oesterling JE: Prostate-specific antigen. Improving its ability to diagnose early prostate cancer. JAMA. 1992; 22-29; 267: 2236-8.

9. Benson MC, Whang IS, Olsson CA, McMahon DJ, Cooner WH: The use of prostate specific antigen density to enhance the predictive value of intermediate levels of serum prostate specific antigen. J Urol. 1992; 147: 817-21.

10. Smith DS, Catalona WJ: The nature of prostate cancer detected through prostate specific antigen based screening. J Urol. 1994; 152: 1732-6.

11. Carter HB, Pearson JD: PSA velocity for the diagnosis of early prostate cancer. A new concept. Urol Clin North Am. 1993; 20: 665-70.

12. Polascik TJ, Oesterling JE, Partin AW: Prostate specific antigen: a decade of discovery - what we have learned and where we are going. J Urol. 1999; 162: 293-306.

13. Roehrborn CG, Pickens GJ, Carmody T 3rd: Variability of repeated serum prostate-specific antigen (PSA) measurements within less than 90 days in a well-defined patient population. Urology. 1996; 47: 59-66.

14. Carter HB, Pearson JD, Metter EJ, Brant LJ, Chan DW, Andres R, et al.: Longitudinal evaluation of prostatespecific antigen levels in men with and without prostate disease. JAMA. 1992; 267: 2215-20.

15. Littrup PJ, Kane RA, Mettlin CJ, Murphy GP, Lee F, Toi A, et al.: Cost-effective prostate cancer detection. Reduction of low-yield biopsies. Investigators of the American Cancer Society National Prostate Cancer Detection Project Cancer. 1994; 74: 3146-58.

16. Djavan B, Zlotta A, Kratzik C, Remzi M, Seitz C, 
Schulman CC, et al.: PSA, PSA density, PSA density of transition zone, free/total PSA ratio, and PSA velocity for early detection of prostate cancer in men with serum PSA 2.5 to $4.0 \mathrm{ng} / \mathrm{mL}$. Urology. 1999; 54: 517-22.

17. Thiel R, Pearson JD, Epstein JI, Walsh PC, Carter HB: Role of prostate-specific antigen velocity in prediction of final pathologic stage in men with localized prostate cancer. Urology. 1997; 49: 716-20.

18. Mettlin C, Jones G, Averette H, Gusberg SB, Murphy GP: Defining and updating the American Cancer Society guidelines for the cancer-related checkup: pros- tate and endometrial cancers. CA Cancer J Clin. 1993; 43: 42-6.

19. Brawer MK, Beatie J, Wener MH, Vessella RL, Preston SD, Lange PH: Screening for prostatic carcinoma with prostate specific antigen: results of the second year. J Urol. 1993; 150: 106-9.

20. Schmid HP, McNeal JE, Stamey TA: Observations on the doubling time of prostate cancer. The use of serial prostate-specific antigen in patients with untreated disease as a measure of increasing cancer volume. Cancer. 1993; 71: 2031-40.

Received: November 24, 2003 Accepted after revision: February 13, 2004

\footnotetext{
$\overline{\text { Correspondence address: }}$

Dr. Marcos Dall'Oglio

Rua Manoel da Nóbrega, 853 / casa 22

São Paulo, SP, 04001-084, Brazil

Fax: + $55113885-0658$
} 